\title{
NIGHT VENTILATION STRATEGY ON HOUSING ESTATE IN WARM HUMID TROPIC WITH SURABAYA REFERENCE
}

\author{
Ima Defiana \\ Department of Architecture, Institute of Technology Sepuluh Nopember, \\ Indonesia \\ e-mail: imadefiana1@gmail.com
}

\begin{abstract}
This study is about night ventilation in dry climates often related to thermal mass. All the opening closed during daytime, to provide lower indoor temperature. According to bioclimatic context, Surabaya as warm humid reference, air movement is needed to restore humidity for all the time. This research concerned in promoting air movement, in order to maintain thermal comfort during night time. Opening schedule is proposed as factor which contributes the function of night ventilation in warm humid climate. Simulations were performed in steady state conditions, used models based on expanded-type 60 houses of grid pattern housing estates in Surabaya. 2 model site plan used as case studies. Air movement in bed room and living room has been investigated to maintain thermal comfort. Results show that night time ventilation in warm humid climate is accomplished by outdoor and indoor space configurations. The windows and door are proposed to open at 5.00 p.m. to 6.00 a.m. For supporting night time ventilation in warm humid, the outdoor space configurations are determined by building coverage ratio of 50-60\%, $0.7 \mathrm{H} / \mathrm{W}$ at backside of building for wind parallel to the street or $1.3 \mathrm{H} / \mathrm{W}$ for wind perpendicular to the street. Occupants could expand thermal comfort zone with air flow of 0.4-0.8 m/sec for wind parallel to the street and 0.4-0.55 for wind perpendicular to the street.
\end{abstract}

Keywords: CFD simulation, housing estat,; warm humid climate

\section{INTRODUCTION}

Sustainable architecture is an effort to reduce global warming (Williams, 2003). Energy conservations for operations building (end-use energy) is one form of sustainable architecture (Edwards, 1996). It can be performed using passive design in accordance with the function of the building and the local climatic conditions (Williams, 2003). The building design based on climate is called bioclimatic design (Olgyay, 1963). 
In the context of bioclimatic design, a natural ventilation system is suitable for passive cooling in warm humid tropic (Szokolay, 2004). There are two strategies for natural ventilation achievement, namely comfort ventilaton or day ventilation and nocturnal convective ventilation. Both of them have different goals and parameters. Nocturnal convective ventilation as referred to night flush cooling. Generally, the mechanism is open the window at night time, utilizing cold stored in the structure or building materials used for cooling during the day. To achieve these objectives, during the day, all window is closed (Lechner 2009). This strategy is widely used in dry tropical climates, where the temperature difference between day and night is more than $10 \mathrm{~K}$, thus the reduction of room temperature at daytime, due to this strategy is important and supported by the thickness of material.

Increasing of indoor temperature at nighttime is affected by accumulation of internal heat gains and heat gain from the building envelope as a result of the time lag of materials (Defiana,2007). Internal heat gain received through the heat of the occupants, electronic equipment, lighting etc (Puangsombut et al, 2007). Accumulation of indoor high humidity causes the evaporation of sweat and the skin surface becomes inhibited. Therefore, it needs adequate ventilation to divert excess of heat (Szokolay, 2004).

\section{THEORY / METHODS}

Building in the humid tropics rarely utilize night time ventilation, for security reasons, insects and privacy (Ekasiwi, 2007; Kubota, 2009). Bedroom and family room are rooms that have relatively high occupancy rate (Antaryama and Ekasiwi, 2006). Therefore, the bedroom and the living room is conditioned comfortable during the day and night. Generally at night time occupants can not receive the wind flow because windows in a closed, but required considerable comfort for bed room. At the same time, the indoor temperature is higher than the outside of the building, and needed ventilation to move heat gain out of the room through the process of convection. The process of convection can be made through the wind flow mechanism on pressure difference (Szokolay, 2004). The mechanism of pressure differences that occur if the open space available. Eventhough, open space on residential houses are rarely available (Defiana, 2012)

In warm humid tropical, comfort ventilation is required not only during the day but also at night.. The night time ventilation is needed to prevent heat gain accumulation and transfer the heat gain of the room out of the building in order to achieve a physiological cooling. Comfort ventilation relies entirely on natural air movement to give air freshner for occupants. The aim of study provides design strategies to achieve comfort ventilation in the night time for housing estate.

Design of ventilation at night time lies in the context of bioclimatic design in humid tropical. Surabaya is used as a reference for warm humid tropical climate. Wind flow at night time in the humid tropics is required in order to increase the evaporation process, to fulfill thermal comfort. Temperature difference in warm humid tropic lower than the dry tropics. Therefore, the utilization of wind ventilation at nighttime as physiological cooling is done by the pressure difference. In this 
study, the pressure difference as wind driven achieved through outdoor spaces and indoors. The intended design is the availability of open space in the backyard or sideyard, creating a distance between buildings, arrangement of openings and schedule configuration bedrooms and living room.

\section{Research Methods}

The range of thermal comfort is $\pm 2.5 \mathrm{~K}$ from neutral temperature (Szokolay, 2004). Neutral temperature for Surabaya City is $26.2^{\circ} \mathrm{C}$, and range of comfort is $26.2^{\circ} \mathrm{C} \pm 2.5 \mathrm{~K}$. Surabaya has a character of the wind velocity at night is lower than during the day. Air temperature difference inside and outside the room is less than 5K (Defiana, 2012)

Object of research lies in two site plans in East Surabaya. Both of site plan represent the development of residential real-estate in social-economy middle class. Distinctive features are patterned grid. Both tread lies in the same mezo climate zone so that relative thermal environmental conditions have not significant differences. Site plan 1 is YKP Pandugo 2 estate (Figure. 1) and Site plan 2 is Purimas estate (Figure. 2)

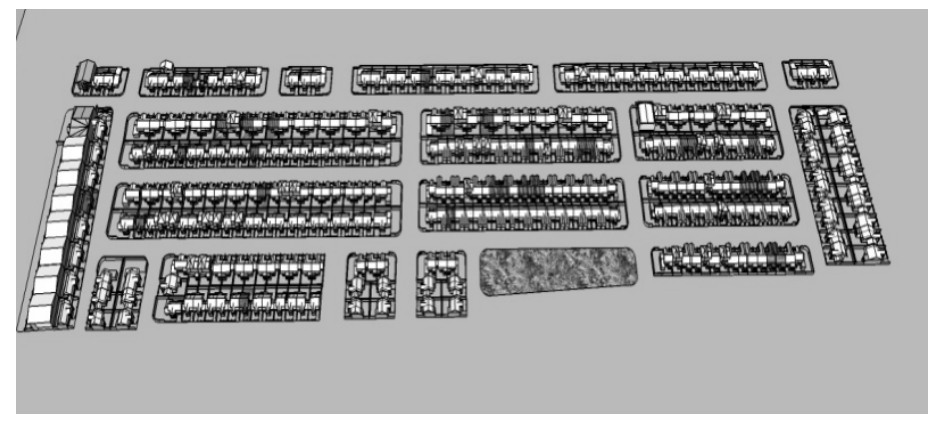

Figure. 1. Site Plan 1

Source: Defiana, 2012

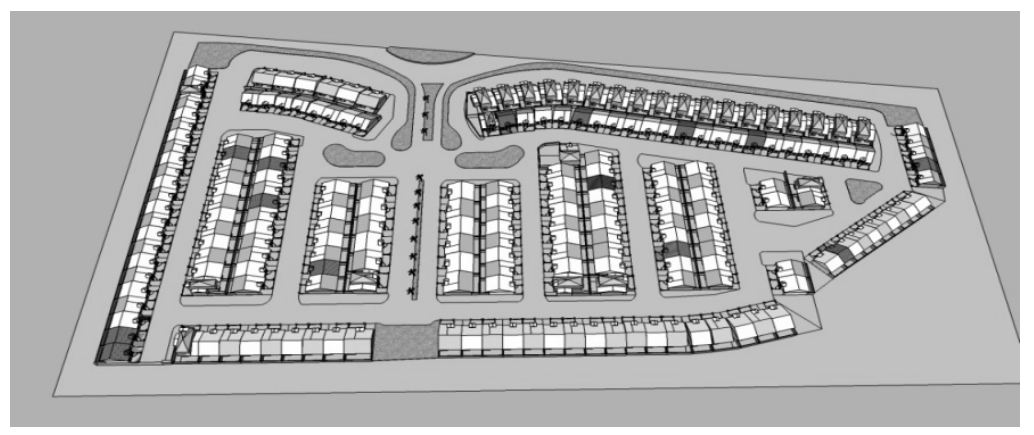

Figure 2. Site Plan 2

Source: Defiana, 2012 
Simulation of the wind velocity outside the building using double precission (dp), Reynolds averaged Navier-Stokes equations (RANS) and standard turbulence models k-C (ske). This equation has been widely used by some previous researchers including Parra et al (2010). This equation is used because of the level of stability and accuracy adequate for the type of fluid flow and the turbulence models are complete.

All model is proposed to have an open space in the rear, porous wall on the boundary wall area, and have three bed rooms. Main bed room in the first floor and two children bedroom in the second floor. Model on site plan 1 has air well as character (Figure 3 ). Model on site plan 2 has a void as character (Figures 4 and 5 ).

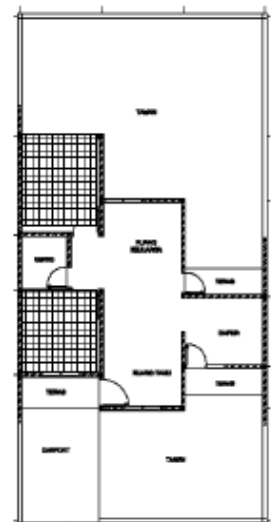

a. Existing

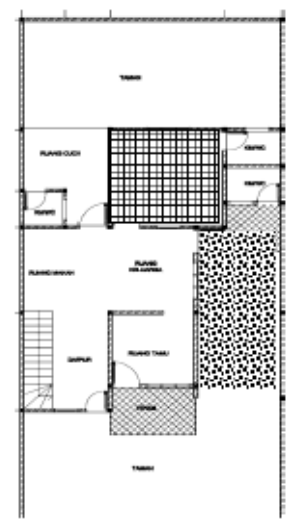

b. First floor

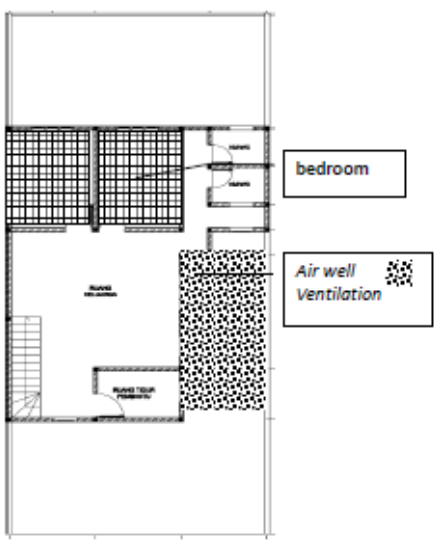

c. Second floor

Figure 3. Proposed Model Simulation on Siteplan 1 Source: Defiana, 2012

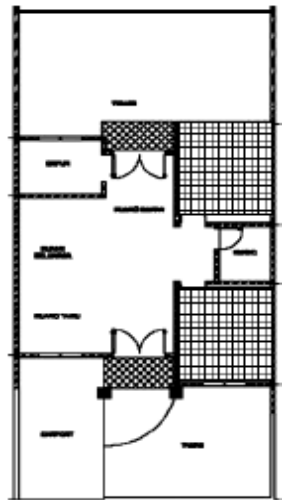

a Existing

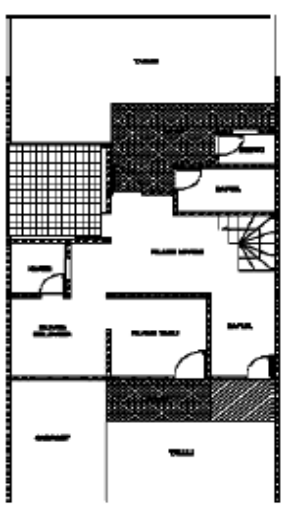

b. First floor

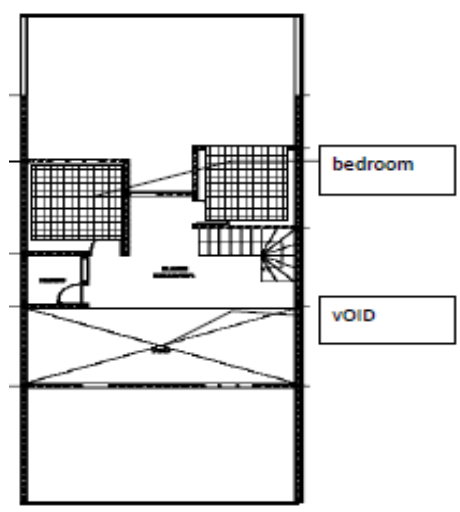

c. Second floor

Figure 4. Proposed Model Simulation on Siteplan 2 Source: Defiana, 2012 


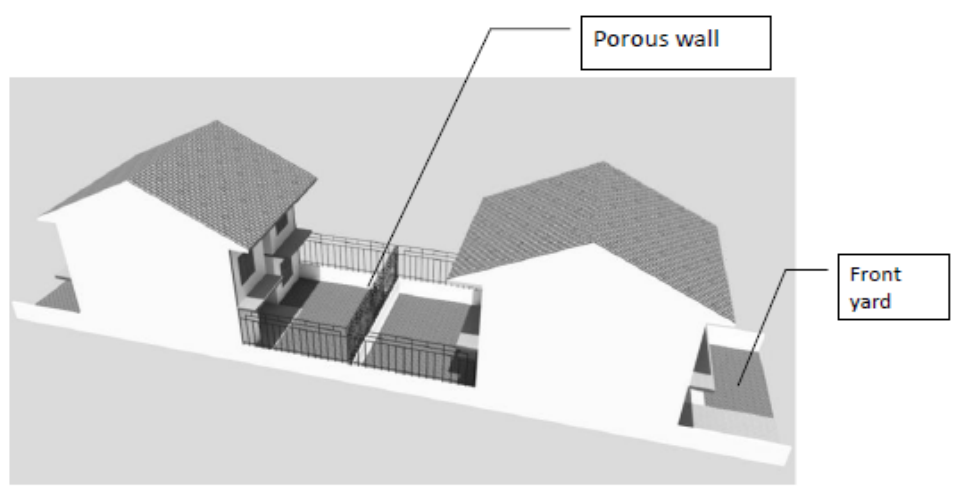

Figure 5. Model on Siteplan 2

Source: Defiana, 2012

\section{RESULTS AND DISCUSSION}

Openings on different sides led to the difference of pressure. Thus create wind flow which flowing from one room to another (see Figures 6 and 7 ). Availability of wind velocity on outside the building affected by the orientation of street. The high difference of pressure between the open space at the back and open space at the front creates a wind velocity which can generate night ventilation system. All site plan have indicate differences of wind orientation. The orientation of the wind influence on the distribution of outdoor wind speed. Distribution of wind at the site plan 2 is $77.8 \%$ better than the first because the site 2 has winds parallel to the road. With the wind orientation parallel to the road, the site 2 has a minimum wind velocity of 1.1-1.7 m/ sec and a maximum speed of 2.8-3.4 m/ sec.

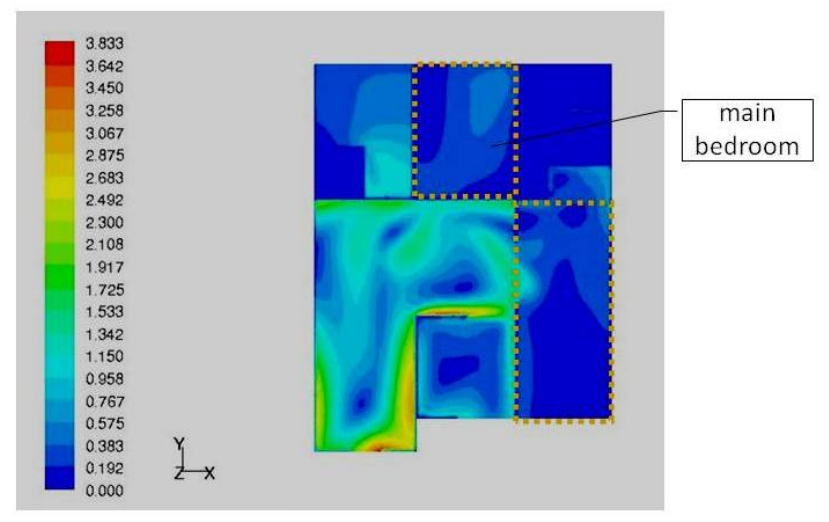

a. First Floor 


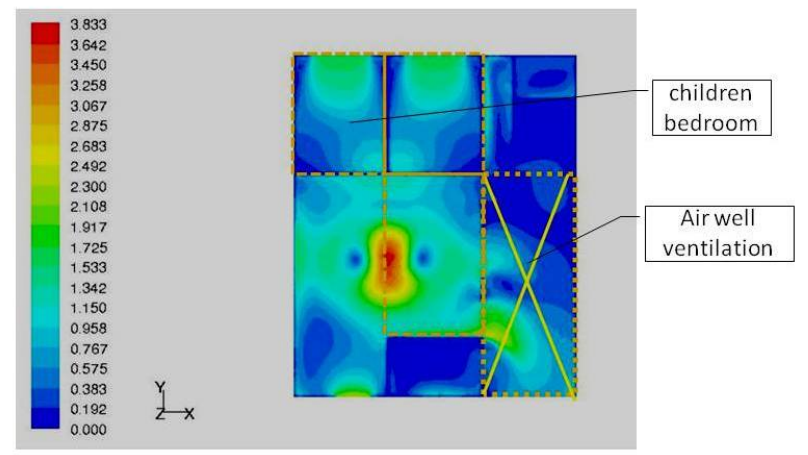

b. Second Floor

Figure 6. Contour of wind velocity on siteplan 1 Source: Defiana, 2012

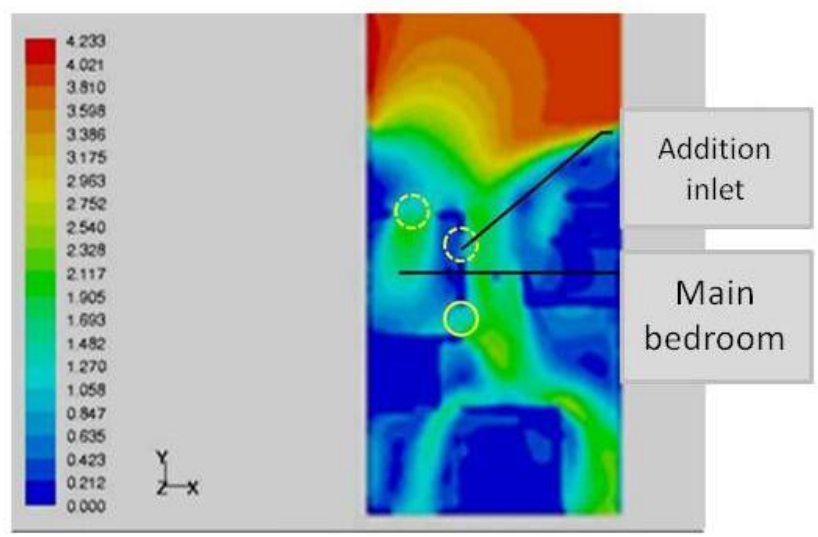

a. First Floor

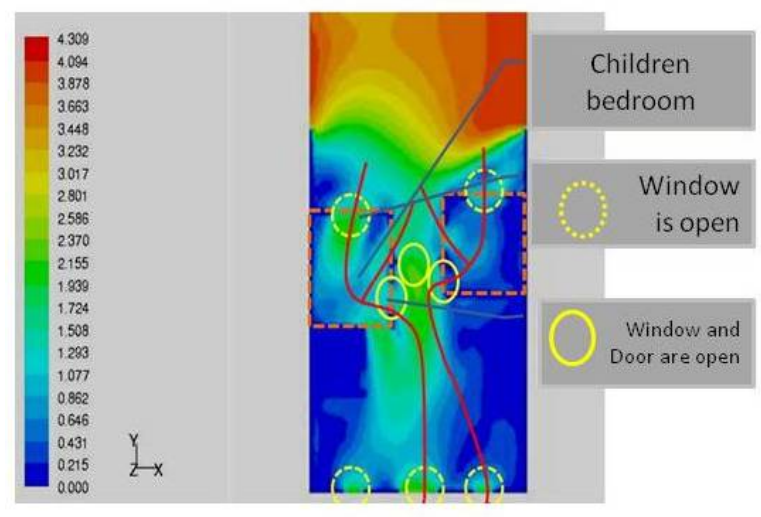

b. Second floor

Figure 7. Contour of Wind Velocity on Siteplan 2

Source: Defiana, 2012 
Ratio base of the building or building coverage ratio (BCR) influence distance between buildings. If BCR is $50-60 \%$, the ratio of $\mathrm{H} / \mathrm{W}$ maximum in rear section is 0.7 (wind parallel to the road) or the ratio $\mathrm{H} / \mathrm{W}$ maximum in rear section is 1.3 ( wind perpendicular streets ) building has wind flow on wake interference flow type. All model simulation have wake interference flow type. The existence of the building located on wake interference flow type provides the potential to maintain thermal comfort at nighttime .

If the wind speed on outside the building is capable to supporting ventilation at night time, it is necessary to design the room configuration and schedule of openings. Configuration space and schedule of openings have an important role in providing wind flow corresponding to the function space, especially for humid tropical. Wind flow corresponding to the activity of the occupants in the room can extend the zone of thermal comfort. Configuration space on the model in the site plan 1 has a air well ventilation as the driving pressure difference, while for the model in the site plan 2 has a void that serves as the driving pressure difference. Air well ventilation or void is required as the driving pressure difference, especially when the wind speed outside is minimum at 01.00

Based on simulation results, to create a large pressure difference at nighttime, doors and windows should open. This is shown in Figures 6 and 7. The air flow of $0.4-0.8 \mathrm{~m} / \mathrm{sec}$ for wind parallel to the street and 0.4-0.55 for wind perpendicular to the street.

\section{CONCLUSIONS}

In the natural ventilation, wind flow from the outside of the building system can achieve in room through the external openings which is facing the open space. The more space that have an external opening will receive higher wind flow. Therefore, it is necessary to maintain distance between buildings at the front and at rear.

The existence of open space at the front or at the rear of the housing is affected by building coverage ratio. The application of a low ratio indicates the building can have an open space at the front and at the rear. The existence of open space at the back can serve as an inlet if there is sufficient distance. Design strategies for achieve ventilation in the night time, first : windows and door are proposed to open at $5.00 \mathrm{p} . \mathrm{m}$. to $6.00 \mathrm{a} . \mathrm{m}$, second : building coverage ratio of 50 $60 \%$, third : $0.7 \mathrm{H} / \mathrm{W}$ at backside of building for wind paralell to the street or 1.3 $\mathrm{H} / \mathrm{W}$ for wind perpendicular to the street.

\section{ACKNOWLEDGMENT}

The authors would like to thank Mrs. Luh Mas Ariyati SE, Adv Dipl BA, MPd as proof reader for this paper 


\section{REFERENCES}

Defiana, Ima (2007), The Influence of Building Orientation in Energy Operational on Hot Humid Tropical Housing (Case study: Housing in Rungkut YKPSurabaya), International Conference 'Sustainability in Rain, Sun and Wind' The 8th, SENVAR, University of Petra - Surabaya, Agustus 2007

Defiana, Ima (2012), Piramida Night Ventilation: Paradigma Penyejukan Fisiologis Untuk Rumah Sederhana Real estate di Daerah Tropis Lembab, Disertasi Doktor, Jurusan Arsitektur, Institut Teknologi Sepuluh Nopember, Surabaya, Indonesia

Edwards, Brian (1996), Towards sustainable architecture, Butterworth architecture, Butterworth-Heinemann, Linacre House, Jordan Hill, Oxford

Ekasiwi, Nugraheni SN (2007), 'Night ventilation for improving thermal environment in bedroom of houses in warm humid region', Journal of Architecture and environment, volume 6 no 1, 2007.

Kubota, Tetsu; Chyee DTH; Ahmad, Supian (2009), 'The effects of night ventilation technique on indoor thermal environment for residential buildings in hothumid climate of Malaysia', Energy and Buildings 41 (2009) 829-839

Lechner, Norberg (2009), Heating, cooling, lighting. Sustainable design methods for architects. John Wiley and sons, Canada

Olgyay, Victor (1963), Design with Climate, Bioclimatic approach to architectural regionalism, Princenton University Press, Princenton, New Jersey

Parra, MA dkk (2010), 'A methodology to urban air quality assesment during large time periods of winter using computational fluid dynamics models', Atmospheric Environment 44 (2010), page 2089-2097

Puangsombut W, dkk (2007), 'Enhancement of natural ventilation rate and attic heat gain reduction of roof solar collector using radiant barrier', Building and Environment 42, 2007 page 2218-2226

Williamson Terry, Radford Antony, Bennetts Helen (2003), Understanding Sustainable Architecture, Spon Press-London 